Vol.45, n. 3 : pp. 277-286, September 2002

ISSN 1516-8913 Printed in Brazil

BRAZILIAN ARCHIVES OF BIOLOGY AND TECHNOLOGY

AN INTERNATIONAL JOURNAL

\title{
Anatomical Study of Somatic Embryogenesis in Glycine max (L.) Merrill
}

\author{
Juliana Aparecida Fernando ${ }^{1 *}$; Maria Lúcia Carneiro Vieira ${ }^{2}$; Isaías Olívio Geraldi ${ }^{2}$ and \\ Beatriz Appezzato-da-Glória ${ }^{1}$ \\ ${ }^{1}$ Depto. de Ciências Biológicas-ESALQ-USP; C. P. 09; 13418-900; Piracicaba-SP - Brazil. ${ }^{2}$ Depto. de Genética- \\ ESALQ-USP; C. P. 83; 13400-970; Piracicaba - SP - Brazil
}

\begin{abstract}
A comparative anatomical analysis of somatic embryogenesis in two soybean (Glycine max (L.) Merrill) genotypes was carried out. The somatic embryos were originated from cotyledonary explants obtained from immature zygotic embryos. The medium used for somatic embryogenesis induction was Murashige and Skoog, 1962, salts and Gamborg et al., 1968, vitamins (MSB) supplemented with $0.8 \mathrm{mg} . \mathrm{L}^{-1}$ of 2,4-D for genotype PI 123439 and $40 \mathrm{mg} . \mathrm{L}^{-1}$ of 2,4-D for 'Williams 82'. Globular structures, constituted by meristematic cells, originated from subepidermal cell divisions of the cotyledonary mesophyll. In PI 123439, the globular structures presented tracheary differentiation among meristematic cells and they could follow distinct morphogenetic process depending on their location along the explant. For 'Williams 82' it was observed globular structures along the cotyledonary explant surface. They gave rise to somatic embryos. These embryos showed different morphologies and they were classified based on their shape and number of cotyledons. The ability of these morphological types to convert to plantlets was discussed.
\end{abstract}

Key words: Glycine max, anatomy, somatic embryogenesis, 2,4 -D

\section{INTRODUCTION}

Several protocols for soybean plant regeneration via somatic embryogenesis have been documented (Bailey et al., 1993). The efficiency of these protocols is often associated to the use of 2,4-D (2,4-dichlorophenoxyacetic acid) as auxin source, but conflicting results are obtained concerning their effects at different conce ntrations (Hartweck et al., 1988). High concentration of 2,4-D (20 to $40 \mathrm{mg} . \mathrm{L}^{-1}$ ) improved the frequency of normal somatic embryos comparing to $5 \mathrm{mg} . \mathrm{L}^{-1}$ (Ranch et al., 1986). However, morphological abnormalities have been associated to the use of high concentrations of this auxin.

Considering that histological characterization of soybean somatic embryogenesis has been little reported (Hartweck et al., 1988; Liu et al., 1992; Kaltchuck-Santos et al., 1997) and the applicability of regeneration protocols to the genetic manipulations depends on the analysis of the origin and development of the somatic embryos (Hartweck et al., 1988), this study presents a histological and ultrastructural analysis of the embryogenic process in two soybean genotypes.

\footnotetext{
*Author for correspondence
} 


\section{MATERIAL AND METHODS}

a) Induction of somatic embryogenesis

PI 123439 and 'Williams 82' immature pods were harvested and disinfected by immersing in $70 \%$ alcohol for 40 seconds followed by 15 minutes in a $1 \% \mathrm{NaOCl}(\mathrm{v} / \mathrm{v}$, sodium hypochlorite) solution, then rinsed in sterile distilled water at least four times. Immature zygotic embryos were assepticaly removed from the seeds. The embryonary axis was excised and the cotyledons, not longer than $5 \mathrm{~mm}$, were placed with abaxial surface on the medium. The explants were inoculated in MSB culture medium containing MS salts (Murashige and Skoog, 1962) and B5 vitamins (Gamborg et al., 1968), 3\% (w/v) sucrose and 0.2\% (w/v) Phytagel (Sigma). The PI 123439 explants were kept for 30 days in MSB medium supplemented with 0.8 mg. $\mathrm{L}^{-1}$ of 2,4-D. The $\mathrm{pH}$ was adjusted to 5.8. The cultures were maintained at an irradiance of 30 $\mu$ mol. $\mathrm{m}^{-2} . \mathrm{s}^{-1}$. The 'Williams 82 ' explants were kept for 10 days in MSB medium supplemented with $40 \mathrm{mg} . \mathrm{L}^{-1}$ of $2,4-\mathrm{D}$. The $\mathrm{pH}$ was adjusted to 7.0. The cultures were maintained at an irradiance of 5 to $8 \mu \mathrm{mol} \cdot \mathrm{m}^{-2} \cdot \mathrm{s}^{-1}$. After this period the cotyledonary explants were placed on MSB containing $6 \%$ maltose, $0.5 \%$ activated charcoal and $0.2 \%(\mathrm{w} / \mathrm{v})$ Phytagel (Sigma). The $\mathrm{pH}$ was adjusted to 5.8. All media were autoclaved at 120 ${ }^{\circ} \mathrm{C}$ for 20 minutes and the cultures were maintained at $25 \pm 2{ }^{\circ} \mathrm{C}$ with a $16 \mathrm{~h}$ photoperiod.

\section{b) Histological and ultrastructural analysis}

PI 123439 and 'Williams 82' cotyledonary explants exhibiting somatic embryos at different development stages were collected during the induction process. These samples were fixed in Karnovsky solution (Karnovsky, 1965). After fixation, samples were dehydrated through an ethanol series, and infiltrated with glycol methacrylate resin (Reichert-Jung, Germany). Sections were cut $(5 \mu \mathrm{m})$ and stained with $0.05 \%$ toluidine blue O (Sakai, 1973). All samples were observed with a Nikon AFX-DX (Labophot) microscope. For scanning electron microscopy, somatic embryos were fixed in Karnovsky solution (Karnovsky, 1965), dehydrated in ethanol, dried to a critical point of $\mathrm{CO}_{2}$ and attached to aluminum stubs. Samples were coated with gold (30 - $40 \mathrm{~nm}$ ) and examined in Scanning electron microscope (Zeiss, DSM 940A, $5 \mathrm{kV}$ ).

\section{RESULTS AND DISCUSSION}

PI 123439 explants gave rise to globular structures on the cotyledonary surface (Fig. 1A). Histological studies showed that globular structures were originated from subepidermal cell divisions in the cotyledonary mesophyll and the protuberance was covered by the epidermis. Generally, tracheary differentiation was observed among the meristematic cells of the protuberances (Fig. 1B and D, arrow). These globular structures elongated and they gave rise to somatic embryos (Fig. 1C) or roots (Fig. 1F). The globular structures that formed somatic embryos, exhibiting clear bipolarity, were observed at the submarginal region of the explant (Fig. 1A and B). However, the structures that formed roots were observed along the explant surface (Fig. 1E).

Hartweck et al., 1988, described non-embryogenic meristematic zones along the G.max explants that originated roots and neomorphic protuberances. According to them, the embryogenic zone was only located at the submarginal region. However, in the present study, the same morphoanatomical type of protrusion may develop into somatic embryos (Fig. 2A-E) or roots (Fig. 1F) and only the submarginal protrusions originated somatic embryos, as reported by Hartweck et al., 1988. Probably the variation on morphogenetic structures is related to polar accumulation of an endogenous hormone which may produce the somatic embryos of PI 123439 on the periphery explants. The root formation along the cotyledonary explant surface in Panax ginseng, occurred due to a low hormonal level in this region (Choi and Soh, 1996).

The globular structures that followed the embryogenic process have developed into abnormal somatic embryos with multiple cotyledons (Fig. 2A and E). However, it was possible to verify root meristem and meristematic areas associated to each cotyledonary structure (Fig. 2E, arrowheads), as observed in Vitis spp. somatic embryos (Passos et al., 1999). The precocious tracheary differentiation in the embryonary axis and the storage of substances, mainly starch, common for PI 123439 somatic 
embryos, have been associated to precocious germination (Passos et al., 1999).

Embryogenesis in cultured cells was highly repetitive and somatic embryos could bear smaller embryos along their axes and sometimes restricted to certain loci such as radicle-hypocotyl junction (Ammirato, 1987), as it was observed for PI 123439 (Fig. 2B-D) and for Vitis spp (Passos et al., 1999). The ultrastructure and anatomical analysis of these secondary embryos (Fig. 2C and D) showed embryos exhibiting shoot and root apices (Fig. 2D, arrow). The secondary embryogenesis in Trifolium repens was associated with repression of normal development of primary somatic embryos (Maheswaran and Williams, 1985).

'Williams 82 ' somatic embryos were noted after 8 days in MSB medium containing $0.5 \%$ activated charcoal. The somatic embryogenesis occurred directly from cotyledonary explant, without a callus phase, as it was related previously for PI 123439. Similarly, Yuqing et al., 1995, reported embryogenic structures formation of different $G$. max genotypes directly from the cotyledon explant.

The globular structures also presented continuous epidermis with the explant tissue (Fig. 3A-C) and they arised from subepidermal cell divisions of the cotyledonary mesophyll, characterizing a multicellular origin of the somatic embryos (Fig. 4C, detail). However, these pre-globular embryos not presented precocious tracheary differentiation as described for PI 123439 somatic embryos.

In both studied soybean genotypes none of the embryos presented unicellular origin nor suspensor-like organ structures (Figures $3 \mathrm{~F}$ and 4A-C). Somatic embryos with multicellular origin appears to produce the embryonary axis basis widely linked to the explant without a suspensor like organ or equivalent structure formation (Williams and Maheswaram, 1986; Dornelas et al., 1992). According to these authors, somatic embryos sometimes may be linked to the explant by embryonary axis as it was verified in the present study (Fig. 4B).

Hartweck et al. (1988) reported that G. $\max$ somatic embryos induced by $10 \mathrm{mg} . \mathrm{L}^{-1}$ of NAA had unicellular or multicellular origin, however embryos induced in medium supplemented with high concentration of 2,4-D (25 mg. $\left.\mathrm{L}^{-1}\right)$ had always multicellular origin, confirming the observations of this study.

'Williams 82' somatic embryos were formed along the immature cotyledonary surface of the explant. It seems to exist a relation between explant orientation and the auxin concentration. According to Hartweck et al., 1988, the abaxial surface of the explants placed on the medium with high concentration of 2,4-D were stimulated to form somatic embryos in the central region of the cotyledonary explant, as it was observed in this study for 'Williams 82'. However, the authors verified that adaxial explants with 2,4-D low concentration presented somatic embryos on the explant periphery, as it was verified for PI 123439 in the medium supplemented with $0.8 \mathrm{mg} . \mathrm{L}^{-1} 2,4-\mathrm{D}$.

Pre-globular somatic embryos of 'Williams 82' formed independently (Fig. 3A and B) or very close (Fig. 3C, arrow). The isolated pre-globular somatic embryos developed to embryological later stages, arising globular, heart (Fig. 3D and E) and torpedo somatic embryos (Figures $3 \mathrm{~F}$ and $4 \mathrm{~A}$ ) not depending on the explant tissue and exhibiting close vascular system. Otherwise, the pre-globular somatic embryos that were formed very close (Fig. $3 \mathrm{C}$, arrow), in a later developmental stage, appear to be linked by their basal region (Fig. 4C).

The somatic embryogenesis was not synchronous (Fig. 4C). Globular somatic embryos could be observed together with embryol ogical later stages, as described in Stylosanthes scabra, Carya illinoinensis and Vitis by Dornelas et al., 1992, Rodriguez and Wetsztein (1994) and Passos et al., 1999, respectively.

In this paper, the most frequent abnormality was cone-shaped cotyledonary (Fig. 5A e B). These embryos presented root meristem, but the shoot meristem was absent (Fig. 5B). Hartweck et al., 1988, characterized these somatic embryos as trumpet. This morphological type germinated but failed to convert into plantlets.

Somatic embryos presenting a single cotyledon were classified as monocotyledonary (Fig. 5C). It was observed anisocotyledonary somatic embryos (Fig. 5D) which presented one prominent cotyledon and the other, small and rudimentary. These two morphological patterns were occasionally able to convert into plantlets. 


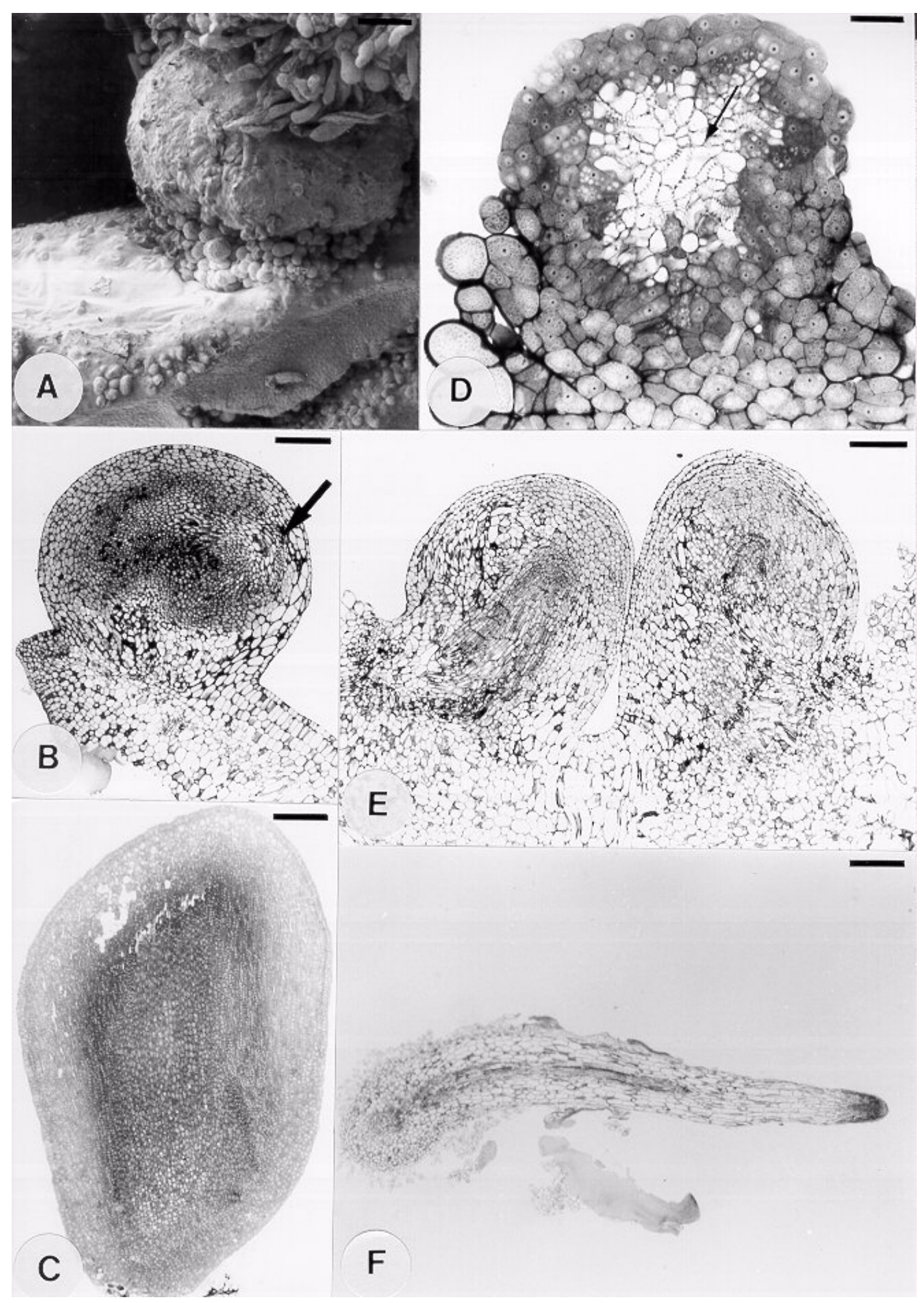

Figure 1 - Glycine $\max$ (PI 123439). A. Electron micrograph of globular structure at the distal periphery explant (bar $=200 \mu \mathrm{m}) ;$ B. Longitudinal section of globular structure showing continuous epidermis and tracheary differentiation (arrow, bar $=275 \mu \mathrm{m}$ ); C. Longitudinal section of somatic embryo originated from globular structure as observed in $\mathbf{B}(\mathrm{bar}=275 \mu \mathrm{m})$; D. Longitudinal section of globular structure showing tracheary differentiation among the meristematic cells $($ bar $=51 \mu \mathrm{m})$; E. Longitudinal section of structures that gave rise to roots sowing vascular connection with the explant (bar $=275 \mu \mathrm{m}) ; \mathbf{F}$. Longitudinal section of a root originated from structures similar to those showed in $\mathbf{E}($ bar $=555 \mu \mathrm{m})$. 


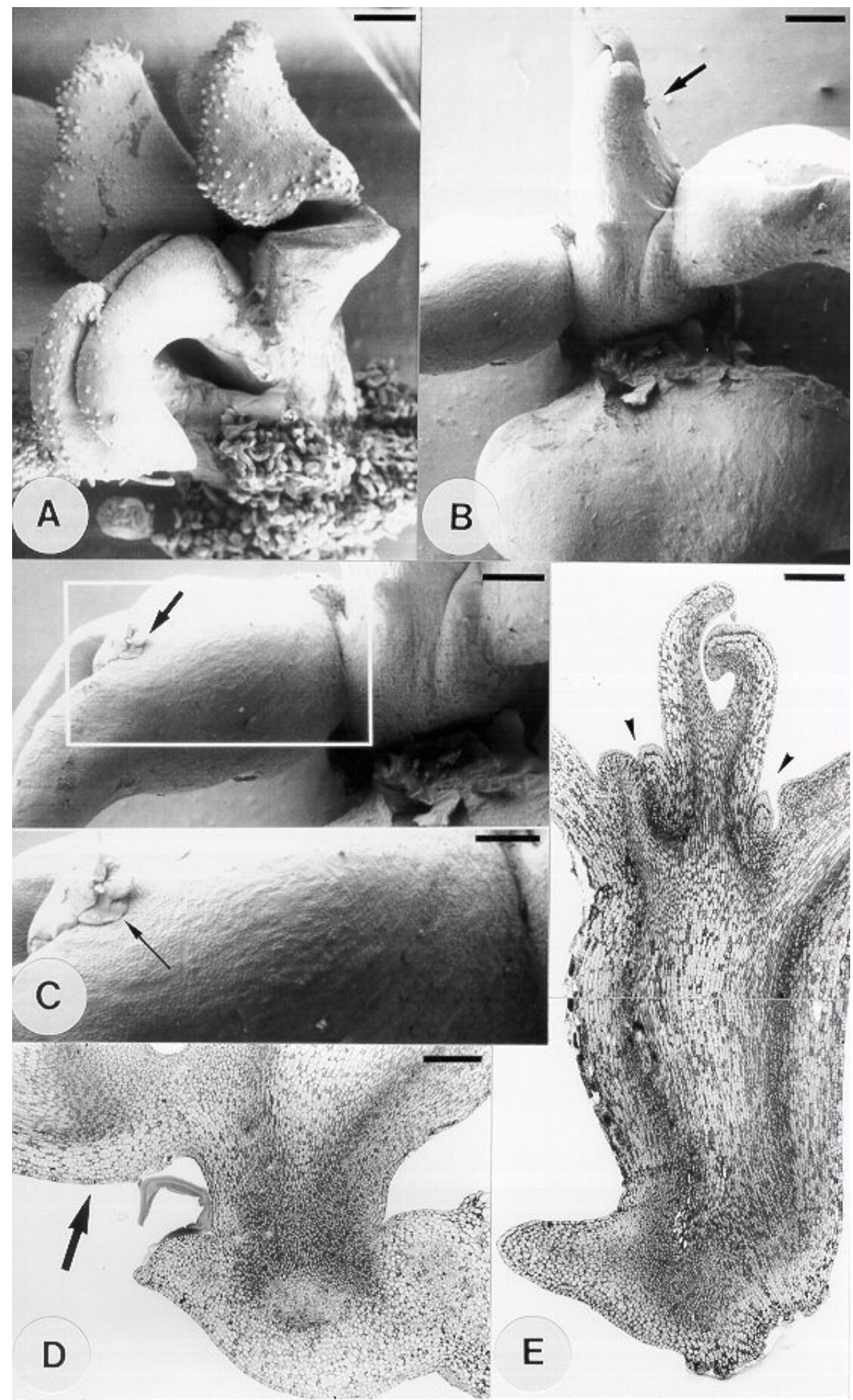

Figure 2 - Somatic embryos (SE) of Glycine max (PI 123439) after 26 days of culture in MSB medium containing $0,8 \mathrm{mg} . \mathrm{L}^{-1}$ of 2,4-D. A. Electron micrograph of SE located at the periphery of cotyledonary explant $(\mathrm{bar}=178 \mu \mathrm{m})$; B. Electron micrograph of two secondary somatic embryos formed between the hypocotyledonary and radicular portion of the primary somatic embryo (arrow, bar $=454 \mu \mathrm{m}$ ). C. Secondary embryos showing shoot meristem (arrow) (bars $=333 \mu \mathrm{m} ; 83 \mu \mathrm{m}) ;$ D. Longitudinal section of the secondary somatic embryo (arrow) $($ bar $=552 \mu \mathrm{m})$; E. Longitudinal section of multicotyledonary somatic embryo; meristematic areas associated to each cotyledonary structure (arrowheads, bar $=552 \mu \mathrm{m})$. 

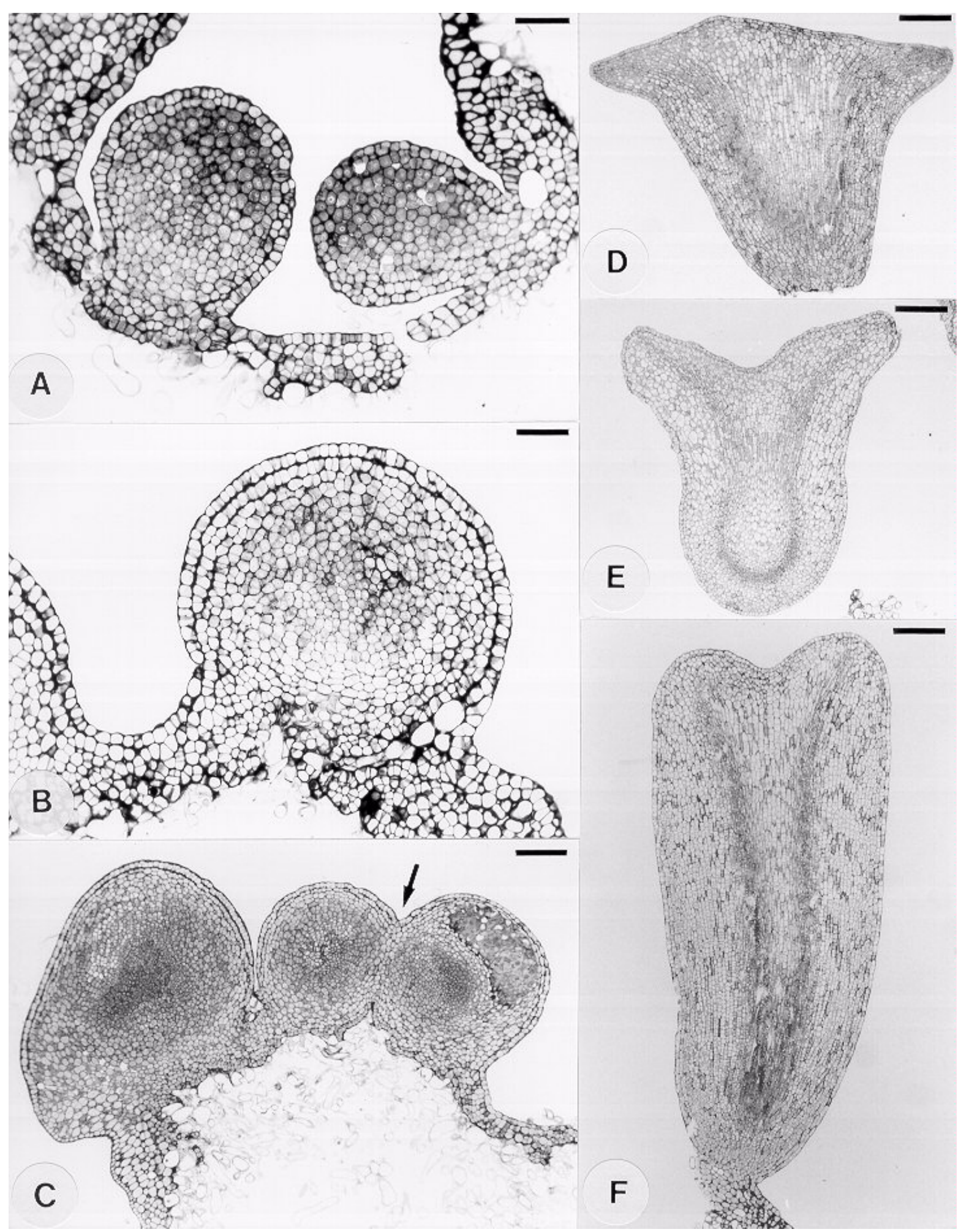

Figure 3 - Somatic embryos of Glycine $\max$ ('Williams 82'). A-C. Pre-globular somatic embryos presenting continuous epidermis with the explant. These globular structures formed independently (A and B, bars $=102 \mu \mathrm{m}$ ) or very close $(C$, arrow, bar $=275 \mu \mathrm{m})$; D-E. Heart-shaped somatic embryos $($ bar $=275 \mu \mathrm{m})$; F. Torpedo somatic embryo (bar $=275 \mu \mathrm{m})$. 


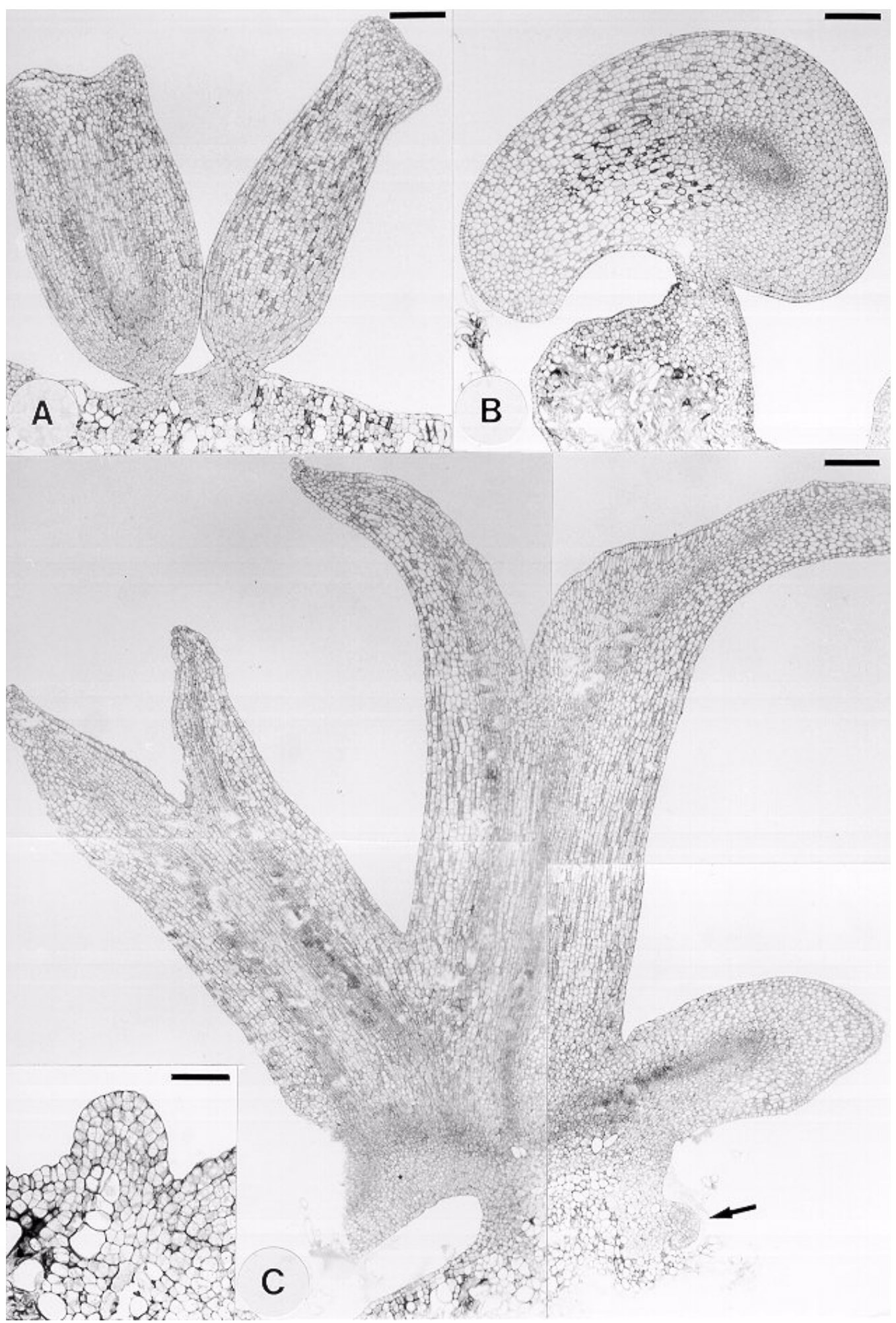

Figure 4 - Longitudinal sections of somatic embryos of Glycine max ('Williams 82'). A. Torpedo somatic embryos exhibiting closed vascular system (bar $=275 \mu \mathrm{m})$; B. Somatic embryo linked to the explant by hypocotyledonary axis $($ bar $=275 \mu \mathrm{m})$; C. Somatic embryos in different embryological stages $($ bar $=275 \mu \mathrm{m})$; detail bar $=102 \mu \mathrm{m})$. 


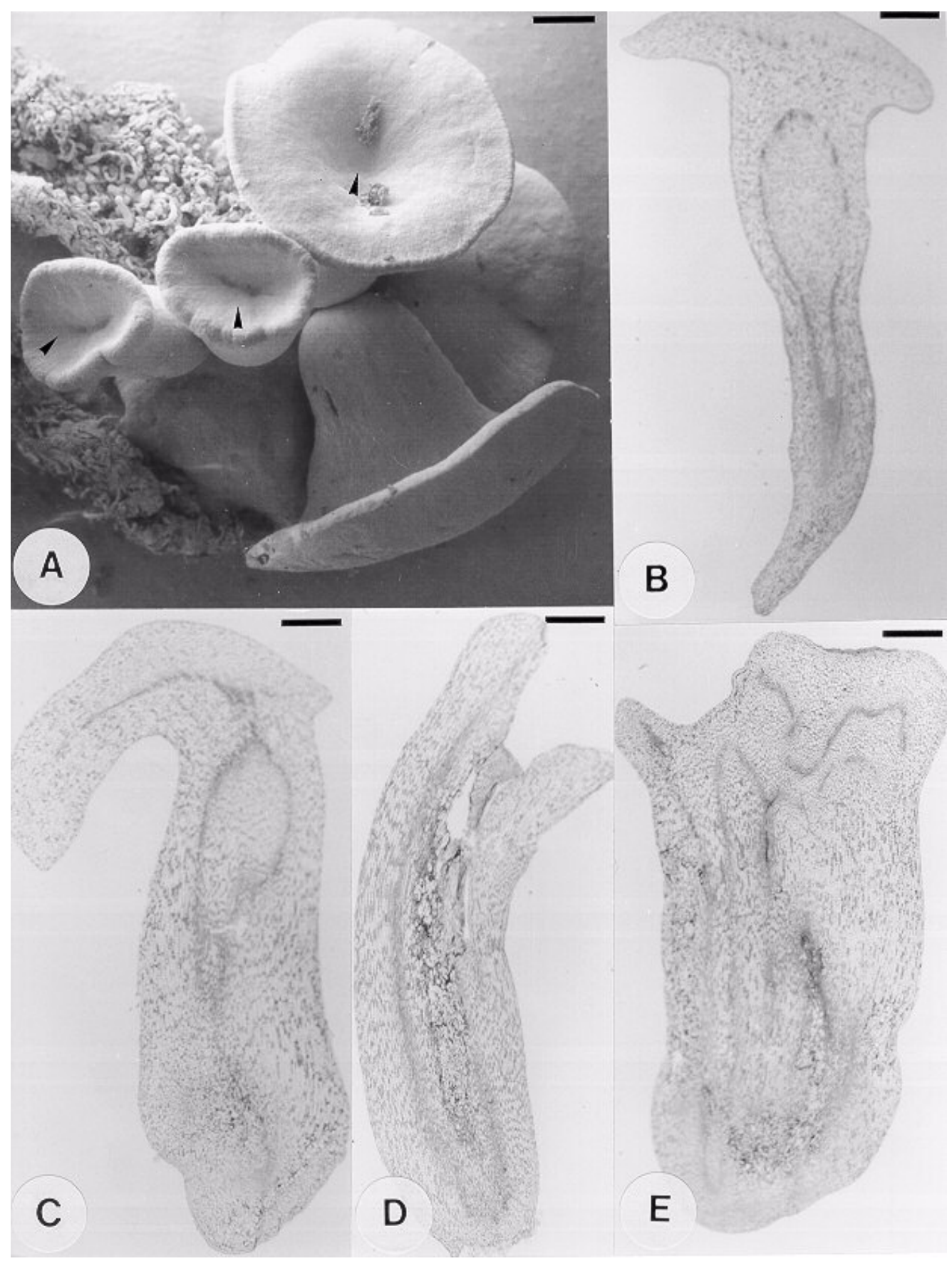

Figure 5 - Somatic embryos of Glycine max ('Williams 82'). A. Electron micrograph of cone-shaped cotyledonary showing absence of shoot meristem (arrowheads) (bar $=384 \mu \mathrm{m}$ ); B. Longitudinal section of cone-shaped cotyledonary $($ bar $=1125 \mu \mathrm{m})$; C. Monocotyledonary somatic embryo $($ bar $=819 \mu \mathrm{m})$; D. Anisocotyledonary somatic embryo $($ bar $=569 \mu \mathrm{m}) ; \mathbf{E}$. Multicotyledonary somatic embryo $($ bar $=757 \mu \mathrm{m})$.

The somatic embryos characterized as multicotyledonary, in initial developmental stage, presented shoot meristem and not fasciated hypocotyledonary axis. These embryos during the culture period showed fasciated hypocotyledonary axis, as it was observed by Chengalrayan et al., 1997, in Arachis hypogaea somatic embryos. The anatomical analysis of these embryos showed an irregular vascularization along the hypocotyledonary axis and absence of shoot 
meristem (Fig. 5E). Only the multicotyledonary embryos in initial developmental stage transferred to germination medium were able to convert, while the fasciated embryos could not co nvert. In Vitis, after the torpedo stage, the embryos showed a teratological behaviour. The shoot apex, always present in the torpedo stage, was not recognizable in the giant embryos. It seems that shoot apex has differentiated and lost its meristematic characteristics as embryogenesis proceeded (Passos et al., 1999).

Root meristem and the occasional shoot meristem formation in G. max abnormal somatic embryos may be related to the precocious germination characterized by the anticipated root development and interruption in meristematic activity at the shoot apex, as described by Passos et al., 1999.

The absence of a well-defined shoot meristem may be responsible for the lack of conversion of these somatic embryos (Suhasini et al., 1996), but the presence of a root meristem allowed that all somatic embryos germinated.

\section{ACKNOWLEDGEMENTS}

We thank the Fundação de Amparo à Pesquisa do Estado de São Paulo (FAPESP) for financial support and to Professor Elliot W. Kitajima from the Microscopic Center of Escola Superior de Agricultura "Luiz de Queiroz", for facilities in the electron microscope analysis; we also acknowledge Mrs. M. K. M. Soares and Mr. C. A. de Oliveira for their excellent technical assistance.

\section{RESUMO}

Realizou-se uma análise anatômica comparativa da embriogênese somática em dois genótipos de soja (Glycine $\max$ (L.) Merrill). Os embriões somáticos foram obtidos a partir de explantes cotiledonares excisados de embriões zigóticos imaturos do genótipo PI 123439, adaptado às condições tropicais, e 'Williams 82'. O meio utilizado para indução da embriogênese somática constituiu-se de sais de Murashige e Skoog,1962, e vitaminas de Gamborg et al., 1968 (MSB) suplementado com $0,8 \mathrm{mg} . \mathrm{L}^{-1}$ de 2,4-D (PI 123439) e $40 \mathrm{mg} . \mathrm{L}^{-1}$ ('Williams 82'). Estruturas globulares originaram-se a partir de divisões celulares nas camadas subepidérmicas do mesofilo cotiledonar e foram constituídas por células meristemáticas. No genótipo PI 123439, as estruturas globulares apresentaram diferenciação traqueal entre as células meristemáticas e seguiram processos morfogenéticos distintos, dependendo da sua localização ao longo do explante. Para 'Williams 82' foram observadas estruturas globulares ao longo de toda a superfície dos explantes cotiledonares. Estas estruturas não apresentaram diferenciação traqueal entre as células meristemáticas e deram origem a embriões somáticos. Esses embriões mostraram uma variedade morfológica, sendo classificados com base no formato e número de cotilédones. A capacidade de conversão dos diferentes tipos morfológicos foi discutida.

\section{REFERENCES}

Ammirato, P. V. (1987), Organizational events during somatic embryogenesis. Paper presented at the 6th International Congress on Plant Tissue Culture, New York, 1986. Plant Biology. Green, C. E.; Somers, D. A.; Hackett, W. P.; Biesboer, D. D. and Liss, A. R. (eds.). New York. pp.57-81.

Bailey, M. A.; Boerma, H. R. and Parrott, W. A. (1993), Genotype effects on proliferative embryogenesis and plant regeneration of soybean. In Vitro Cell. and Dev. Biol., 29 : (3), 102-108.

Chengalrayan, K.; Mhaske, V. B. and Hazra, S. (1997), High-frequency conversion of abnormal peanut somatic embryos. Plant Cell Rep., 16 : (11), 783-786.

Choi, Y. E. and Soh, W. Y. (1996), Effect of plumule and radicle on somatic embryogenesis in the cultures of ginseng zygotic embryos. Plant Cell Tissue and Organ Cult., 45, 137-143.

Dornelas, M. C.; Vieira, M. L. C. and Appezzato-daGlória, B. (1992), Histological analysis of organogenesis and somatic embryogenesis induced in immature tissues of Stylosanthes scabra. Ann Bot., 70, 477-482.

Gamborg, O. L.; Miller, R. A. and Ojima, K. (1968), Nutrient requirements of suspension cultures of soybean root cells. Exp. Cell Res., 50, 151-158.

Hartweck, L. M.; Lazzeri, P. A.; Cui, D.; Collins, G. B. and Williams, E. G. (1988), Auxin-orientation effects on somatic embryogenesis from immature soybean cotyledons. In Vitro Cell. and Dev. Biol., 24 : (8), 821-828. 
Kaltchuk-Santos, E.; Mariath, J. E.; Mundstock, E.; $\mathrm{Hu}$, G. and Bodanese-Zanettini, M. H. (1997), Cytological analysis of early microspore divisions and embryo formation in cultured soybean anthers. Plant Cell Tissue and Organ Cult., 49, 107-115.

Karnovsky, M. J. (1965), A formaldehydeglutaraldehyde fixative of high osmolality for use in electron microscopy. J. Cell Biol., 27, 137-138.

Liu, W.; Moore, P. J. and Collins, G. B. (1992), Somatic embryogenesis in soybean via somatic embryo cycling. In Vitro Cell. and Dev. Biol., 28 : (3), 153-160.

Maheswaran, G. and Williams, E. G. (1985), Origin and development of embryoids formed directly on immature embryos of Trifolium repens in vitro. Ann. Bot., 56 : (5), 619-630.

Murashige, T. and Skoog, F. (1962), A revised medium for rapid growth and bioassays with tobaco tissue cultures. Physiol. Plant., 15, 473-497.

Passos, I. R. S.; Appezzato-da-Glória, B. and Vieira, M. L. C. (1999), Embryogenic responses of Vitis spp.: effects of genotype and polyvinylpyrrolidone. Vitis, 38 : (2), 47-50.

Ranch, J. P.; Oglesby, L. and Zielinski, A. C. (1986), Plant regeneration from tissue cultures of soybean by somatic embryogenesis. In- Vasil, I. K. Cell culture and somatic genetics of plants. 3. ed. New York : Academic Press. pp. 97-109.

Rodriguez, A. P. M. and Wetzstein, H. Y. (1994), The effect of auxin type and concentration on pecan (Carya illinoinensis) somatic embryo morphology and subsequent conversion into plants. Plant Cell Rep., 13 : (11), 607-611.
Sakai, W. S. (1973), Simple method for differential staining of parafilm embedded plant material using toluidine blue 01. Stain Technol., 48, 247-249.

Suhasini, K.; Sagare, A. P. and Krishnamurthy, K. V.. (1996), Study of aberrant morphologies and lack of conversion of somatic embryos of chickpea (Cicer arietinum L.). In Vitro Cell. and Dev. Biol., 32 : (6), 6-10.

Williams, E. G. and Maheswaran, G. (1986), Somatic embryogenesis: factors influencing coordinated behavior of cells as an embryogenic group. Ann. Bot., 57 : (4), 443-462.

Yuqing, F.; Lucchin, M. and Lupotto, E. (1995), Rapid and efficient regeneration from cotyledonary explants of soybean cultivars (Glycine max L.). J. Genet. and Breed., 49 : (4), 339-342.

Received: October 25, 2000; Revised: February 20, 2001; Accepted: June 25, 2001. 